Aan Ansori

\title{
REKAYASA PEMBANGUNAN APLIKASI INDEK KINERJA DOSEN (IKD) BERBASIS WEB DI IAIN SULTAN MAULANA HASANUDDIN BANTEN
}

\begin{abstract}
Abstrak
Rekayasa pembangunan aplikasi IKD merupakan merancang, mendesain aplikasi yang akan dibangun berdasarkan ketentuan dan alur kerja (SOP) dosen yang sudah berlaku secara aturan di dalam organisasi atau instansi yang di implementasikan dalam bentuk logika algoritman yang di terjemahkan dalam bahasa pemrogram (coding program) aplikasi perangkat lunak IKD yang dibentuk dan dapat mengolah data kinerja secara otomatis dalam formulasi aturan perhitungan secara nilai sehingga menghasilkan katagori-katagori penilai dosen secara objektif.

Dosen merupakan pengerak dan pencetak yang akan mewarnai pemikiran dan pengetahuan yang dibentuk pada mahasiswa (transfer knowladge) tentunya dosen harus mempunyai kinerja yang baik dan terukur dalam bidang pengajaran, penelitian dan pengabdian kepada masyarakat, untuk dapat mentransferkan ilmu pengetahuan kepada mahasiswa dalam bidang keilmuan masing-masing dosen untuk dapat meningkatkan dan menghasilkan mahasiswa/mahasiswi yang dapat berkompetisi dan bersaing pada bidangnya di dunia kerja atau di pendidikan selanjutnya.

Penelitian ini dilakukan untuk merekayasa pembanguna sistem aplikasi IKD yang dibentuk dari buku panduan peraturan dosen yang ada dan berlaku di kampus IAIN SMH Banten dan kinerja dosen yang harus dikontrol semua aktifitas kegiatan tridarma dosen dan didokemtasikan melalu aplikasi IKD ini, sehingga semua aktifitas dosen terekam pada database IKD untuk memudahkan pengolahan data kinerja dosen dari awal sampai dengan akhir kegiatan/aktifitas dosen yang bersangkutan dengan cara mengisi username dan passwordnya saja sudah dapat melihat semua kegiatan dosen yang bersangkutan.

Hasil penelitian diperoleh bahwa rekayasa pembanguan aplikasi IKD yang dibentuk sebagai perangkat lunak dapat mendatabasekan semua aktifitas kinerja dosen yang sudah diformulasikan berdasarkan aturan yang berlaku, dosen atau pimpinan dapat memantau/mengetahui data kinerja dosen disetiap semster atau tahun akademik, cukup login pada aplikasi IKD, sudah dapat mengetahui profil dosen dan kinerja dosennya, berdasarkan bukti-bukti akurat yang diisi dan diupload oleh dosen yang bersangkutan.
\end{abstract}

Kata kunci: Rekayasa, aplikasi, SDM. 


\section{A. Pendahuluan}

\section{1) Latar Belakang}

Jaringan global yang kian marak sekarang ini yang dapat diakses dimasa saja dan kapan saja, karena sekarang ini dunia sudah tanpa batas dan dalam genggaman dengan fasilitas gadgetnya dapat melakukan kegiatan jelajah internet.

Peran komputer begitu diperlukan dalam berbagai aspek kehidupan. Komputer juga dapat dimanfaatkan sebagai pendukung dalam memberikan solusi terhadap suatu masalah, ketergantungan akan perangkat keras dan perangkat lunak semakin kedepan semakin diperlukan, teknologi informasi sangat berperan dalam kehidupan manusia sekarang ini, dimana teknologi sudah dapat disaku dan dibawa kemanapun, dan memudahkan bagi penggunanya yang mampu mengoperasikannya, dan teknologi tersebut menyesuaikan dengan fitur-fitur yang mudah dimengerti oleh semua pemakainya, baik pemakai dari anak-anak sampai orang dewasa.

Kualitas institusi pendidikan sangat dipengaruhi oleh masukan bagi sistim pendidikan diantaranya adalah mahasiswa, dosen dan fasilitas saranan pendukung proses belajar mengajar. Ketiga faktor tersebut saling tergantung dan mempengaruhi satu sama lain dalam menciptakan atmosfir pendidikan yang baik.

Dosen adalah seseorang yang berdasarkan pendidikan dan keahliannya diangkat oleh penyelenggara perguruan tinggi dengan tugas utama mengajar. Menurut Undang-Undang Guru dan Dosen nomor 14 tahun 2005, dosen adalah pendidik profesional dari ilmuwan dengan tugas utama metransformasikan, mengembangkan dan menyebarluaskan ilmu pengetahuan, teknologi dan seni melalui pendidikan, penelitian dan pengabdian masyarakat.

Faktor utama penyebab rendahnya mutu pendidikan adalah kondisi pengajar yaitu kualifikasinya tidak layak atau mengajar tidak sesuai bidang keahliannya. Tantangan yang terkait dengan mutu pendidik mencakup tantangan pribadi, kompetensional pribadi maupun ketrampilan pendidik dalam melaksanakan tugasnya.

Kinerja dosen diukur berdasarkan beban kerja dosen mencakup kegiatan pokok yaitu merencanakan pembelajaran, melaksanakan proses bembelajaran, melakukan evaluasi pembelajaran, membimbing dan melatih, melakukan penelitian, melakukan pengabdian pada masyarakat dan melakukan tugas tambahan. Beban kerja dosen sepadan dengan 12 satuan kredit semester (SKS) dan sebanyak banyaknya 16 satuan kredit semester (SKS).

Proses belajar mengajar merupakan suatu proses yang mengandung serangkaian perbuatan pendidik dan peserta didik atas hubungan timbal balik yang berlangsung dalam situasi edukatif untuk mencapai tujuan. Pembelajaran adalah proses interaksi peserta didik dengan pendidik dan sumber belajar pada suatu lingkungan belajar.

Penilaian kinerja berkenaan dengan seberapa baik seseorang melakukan pekerjaan yang ditugaskan/diberikan. Penilaian kinerja formal biasanya berlangsung dalam periode setiap semester. Penilaian kinerja adalah suatu kegiatan yang dilakukan manajemen/penyelia penilai untuk menilai kinerja tenaga kerja dengan cara 
mencatat tanggal penyerahan nilai akhir pada bagian akademik, membuat laporan BKD dan kuestioner yang dilakukan oleh mahasiswa terhadap dosen.

\section{2) Rumusan Masalah}

Rumusan masalah dalam penelitian ini adalah sebagai berikut :

a. Bagaimana konsep dasar Rekayasa Sistem Indek Kinerja Dosen?

b. Bagaimana rancangan rekayasa sistem indek kinerja dosen berbasis website di kampus IAIN Sultan Maulana Hasanuddin Banten?

c. Bagaimana implementasi pembangunan rekayasa sistem indek kinerja dosen berbasis website di kampus IAIN Sultan Maulana Hasanuddin Banten?

\section{3) Tujuan dan Manfaat Penelitian}

Maksud penelitian ini adalah untuk merancang pembangunan rekayasa sistem indek kinerja dosen berbasis website di kampus IAIN Sultan Maulana Hasanuddin Banten sedangkan tujuan dari penelitian ini adalah sebagai berikut:

a. Untuk mengetahui konsep dasar pembangunan Rekayasa Sistem Indek Kinerja Dosen.

b. Untuk mengimplementasikan pembangunan rekayasa sistem indek kinerja dosen berbasis website di kampus IAIN Sultan Maulana Hasanuddin Banten.

c. Untuk membantu dan memudahkan pendataan kinerja dosen dan pengambilan keputusan indek kinerja dosen di kampus IAIN SMH Banten.

Penelitian ini sangat bermanfaat, karena dengan melakukan penelitian ini diperoleh hasil sebagai berikut:

1. Kemudahan Dosen untuk melakukan pemasukan data sendiri baik di kampus maupun di luar kampus?

2. Kuestioner langsung penilaian terhadap Dosen pengajar dapat dilakukan secara online/langsung oleh mahasiswa yang telah memiliki username dan password

3. Pemutahiran data dosen dapat dilakukan langsung oleh dosen yang bersangkutan dengan melampirkan secara softcopy dan di validasi oleh administrator.

4. Penilaian dilakukan secara online/langsung secara objektif secara sistem yang terdapat pada coding program.

5. Coding program dibuat dengan mengacu pada peraturan yang telah ditetntukan oleh lembaga yang berwenag pada kampus IAIN SMH Banten.

6. Memudahkan pelaporan dan pengarsipan dalam bentuk softcopy atau hardcopy

7. Hemat biaya dan efisien waktu dalam pengolahan data Indek Kinerja Dosen dibandingan dengan mengolah data secara manual. 


\section{B. Metodologi Penelitian}

1) Waktu dan Tempat Penelitian

Penelitian ini dilaksanakan pada bulan Februari 2014 sampai dengan September 2014 di IAIN Sultan Maulana Hasanuddin Banten J1. Jendral Sudirman 30 Serang.

\section{2) Alat dan Bahan Penelitian}

Alat dan bahan yang digunakan dalam penelitian ini terdiri dari dua jenis, yaitu perangkat keras (hardware) dan perangkat lunak (software). Perangkat keras yang digunakan adalah Personal Computer (PC) sebagai server dan client, untuk client bisa juga menggunakan laptop atau notebook dengan spesifikasi sebagai berikut:

Tabel 3.1.

Alat dan Bahan Penelitian

\begin{tabular}{|c|l|l|}
\hline No & Nama Perangkat & \multicolumn{1}{c|}{ Spesifikasi } \\
\hline 1 & PC / Laptop & Intel Pentium Dual Core 2.2 GHz, 1 MB DDR2, 250 GB HDD \\
\hline 2 & Hosting Website & $500 \mathrm{Mb}$ \\
\hline 3 & Domain Server & www.ikd.iainbanten.ac.id \\
\hline
\end{tabular}

Sedangkan perangkat lunak yang digunakan dengan spesifikasi sebagai berikut:

Tabel 3.2.

Spesifikasi Perangkat Lunak

\begin{tabular}{|c|l|l|}
\hline No & Nama Software & \multicolumn{1}{c|}{ Spesifikasi } \\
\hline 1 & Xampp & Versi 7.1.2 \\
\hline 2 & Macromedia & Versi 6 \\
\hline 3 & Mysql & Mysq1 5 \\
\hline 4 & PHP & PHP 5 \\
\hline
\end{tabular}

\section{3) Metode Penelitian}

Penelitian ini menggunakan metode studi lapangan karena penelitian ini mengukur implementasi mengenai cara kerja dari aplikasi indek kinerja dosen sebagai perangkat lunak yang berfungsi sebagai pengelolaan data dosen dari profil dosen sampai dengan aktivitas yang dilakukan meliputi kinerja dari pengajaran, penelitian, dan pengabdian kepada masyarakat. 


\section{4) Langkah Penelitian}

Penelitian ini ditujukan untuk merancang dan mengimplementasikan apliasi perangkat lunak indek kinerja dosen sebagai tools atau aplikasi yang dapat digunakan sebagai database dosen tentang kinerja dosen yang ada di IAIN Sultan Maulana Hasanuddin Banten. Secara garis besar, tahapan penelitian terdiri atas 2 tahap, yaitu tahap perancangan/instalasi perangkat lunak untuk mesin platform dari aplikasi IKD yaitu xampp \& perangkat aplikasi program dari IKD yang dibuat dengan bahasa pemrograman PHP.

\section{Kerangka Teori}

\section{Rekayasa Perangkat Lunak (Software Engineering)}

Rekayasa perangkat lunak merupakan sebuah teknologi yang dibentangkan. Banyak pendekatan keteknikan (termasuk software engineering) yang harus berada pada sebuah komitmen dasar menuju kualitas. Alat-alat rekayasa perangkat lunak memberikan topangan yang otamits ataupun semi-otomatis pada proses-proses dan metode-metode yang ada. Ketika alat-alat tersebut diintegrasikan sehingga informasi yang diciptakan oleh satu alat bisa digunakan oleh yang lain, sistem untuk menopang perkembangan perangkat lunak yang disebut computer-aided software engineering (CASE). CASE menggabungkan perangkat lunak, perangkat keras dan database rekayasa perangkat lunak (repositori yang berisi informasi penting tentang analisis, desain, konstruksi program, serta pengujian) untuk menciptakan lingkungan rekayasa perangkat lunak yang analog dengan CAD/CAE (computer-aided design/engineering) untuk perangkat keras.

\section{Pengertian Dosen}

Dosen adalah Pendidik profesional dan ilmuwan dengan tugas utama mentransformasikan, mengembangkan, dan menyebarluaskan ilmu pengetahuan, teknologi, dan seni melalui pendidikan, penelitian, dan pengabdian kepada masyarakat. Dosen mempunyai kedudukan sebagai tenaga profesional pada jenjang pendidikan tinggi yang diangkat sesuai dengan peraturan perundangundangan. ${ }^{2}$

Dosen adalah pendidik dan ilmuwan dengan tugas utama mentransformasikan, mengembangkan, dan menyebarluaskan ilmu pengetahuan, teknologi, dan seni melalui pendidikan, penelitian, dan pengabdian kepada masyarakat. jadi Dosen adalah adalah Pendidik profesional dan ilmuwan dengan tugas utama mentransformasikan, mengembangkan, dan menyebarluaskan ilmu pengetahuan, teknologi, dan seni melalui pendidikan, penelitian, dan pengabdian kepada masyarakat. Dosen mempunyai kedudukan sebagai tenaga profesional pada jenjang pendidikan tinggi yang diangkat sesuai dengan peraturan perundang-undangan.

Kinerja merupakan kondisi yang harus diketahui dan diinformasikan kepada pihak-pihak tertentu untuk mengetahui tingkat pencapaian hasil suatu instansi dihubungkan dengan visi yang diemban suatu organisasi serta mengetahui dampak positif dan negatif suatu kebijakan operasional yang diambil. 
Kinerja didefinisikan sebagai kontribusi terhadap hasil akhir organisasi dalam kaitannya dengan sumber yang dihabiskan (Bain, 1982 dalam McNeese-Smith, 1996) dan harus diukur dengan indikator kualitatif dan kuantitatif (Belcher, 1987; Cohen 1980 dalam McNeese-Smith, 1996). Maka pengembangan instrumen dilakukan untuk menilai persepsi pekerjaan akan kinerja diri mereka sendiri dalam kaitannya dengan item-item seperti output, pencapaian tujuan, pemenuhan deadline, penggunaan jam kerja dan ijin sakit.

\section{Pengantar World Wide Web}

Dokumen ini berisi berbagai penjelasan mengenai World Wide Web mulai dari pengertian internet, sejarah bagaimana awal mula ditemukannya World Wide Web juga berbagai istilah dalam internet serta unsur-unsur yang terdapat dalam Web Site. ${ }^{3}$

\section{Structured Query Language}

Structured Query Language atau SQL adalah bahasa standar yang digunakan untuk memanipulasi dan memeroleh data dari sebuah database relasional. SQL membuat pemrogram dan seorang administrator database dapat melakukan hal-hal berikut: ${ }^{4}$

1).mengubah struktur sebuah database, 2).mengubah pengaturan keamanan sistem, 3).memberikan hak akses kepada pengguna untuk mengakses database/ tabel, 4).memperoleh informasi dari database, 5).memutakhirkan isi database.

\section{MySQL}

SQL (Structured Query Language) adalah bahasa standar yang digunakan untuk mengakses server database. MySQL adalah sebuah server database SQL multiuser dan multi-threaded. SQL sendiri adalah salah satu bahasa database yang paling populer didunia. Implementasi proagram server database ini adalah program daemon 'mysqld' dan beberapa program lain serta beberapa pustaka. ${ }^{5}$

\section{PHP}

PHP adalah teknologi yang diperkenalkan tahun 1994 oleh Rasmus Lerdorf. Beberapa versi awal yang tidak dipublikasikan digunakan pada situs pribadinya untuk mencatat siapa saja yang mengakses daftar riwayat hidup online-nya. Versi pertama digunakan oleh pihak lain pada awal tahun 1995 dan dikenal sebagai Personal Home Page Tools. Terkandung di dalamnya sebuah parser engine (mesin pengurai) yang sangat disederhanakan, yang hanya mampu mengolah macro khusus dan beberapa utilitas yang sering digunakan pada pembuatan home page, seperti buku tamu, pencacah, dan hal semacamnya, sehingga lahirlah PHP/FI. PHP/FI tumbuh dengan pesat, dan orang-orang mulai menyiapkan kode-kode programnya supaya bisa didukung oleh PHP. ${ }^{6}$ 


\section{Pembahasan dan Temuan Penelitian}

\section{1) Hasil Studi Literatur}

Indek kinerja dosen merupakan alat ukur atau barometer untuk mengetahui dari kinerja seorang dosen apakah memenuhi standar kualifikasi yang sesuai dengan aturan yang telah ditetapkan oleh LPM IAIN SMH Banten yang sudah tertulis dalam buku panduan kinerja dosen dan beban kerja dosen (BKD) sebagai langkah awal sebelum kepenilaian kinerja dosen.

Indek Kinerja Dosen merupakan rekayasa pemodelan untuk mengukur kinerja dosen dari mulai dosen melakukan dan merancang Satuan Aktivitas Pengajaran (SAP), absensi masuk kelas mengajar, membuat soal quiz, memberikan tugas dan melakukan penilai terhadap mahasiswa yang terdiri dari nilai Ujian Tengah Semester (UTS) dan nilai Ujian Akhir Semester (UAS) yang kesemua aktivitas tersebut dilalui dengan melakukan proses input data pada sistem yang telah dirancang, sehingga sistem tersebut dapat memformaluasikan logika program yang mengkros-cek antara aktivitas yang telah dimasukan kedalam sistem dengan kuestioner penilai terhadap dosen oleh mahasiswa. Dengan seperti alur proses logika yang sudah tersusun pada sistem tersebut maka didapatkan hasil yang objektive terhadap penilai terhadapa dosen.

Pemodelan yang dibuat dalam bentuk aplikasi perangkat lunak merupakan metode untuk menyelesaikan pendataan dari profil dosen dan aktivitas dalam melakukan tridarma perguruan tinggi yaitu pengajaran, penelitian dan pengabdian masyarakat, yang dibakukan dalam sistem dengan formulasi yang mengacu pada ketentuan-ketentuan yang sudah diatur dan masuk dalam buku kendali mutu yang ada pada Lembaga Penjaminan Mutu (LPM) IAIN SMH Banten sehingga aplikasi sistem indek kinerja dosen dapat berjalan dengan sesaui dengan kententuan-ketentuan yang berlaku dan pengguna hanya melakukan penginputan data saja.

Perancangan Sistematika Alur Rekayasa Pengembangan Aplikasi Indek Kinerja Dosen IAIN SMH Banten 


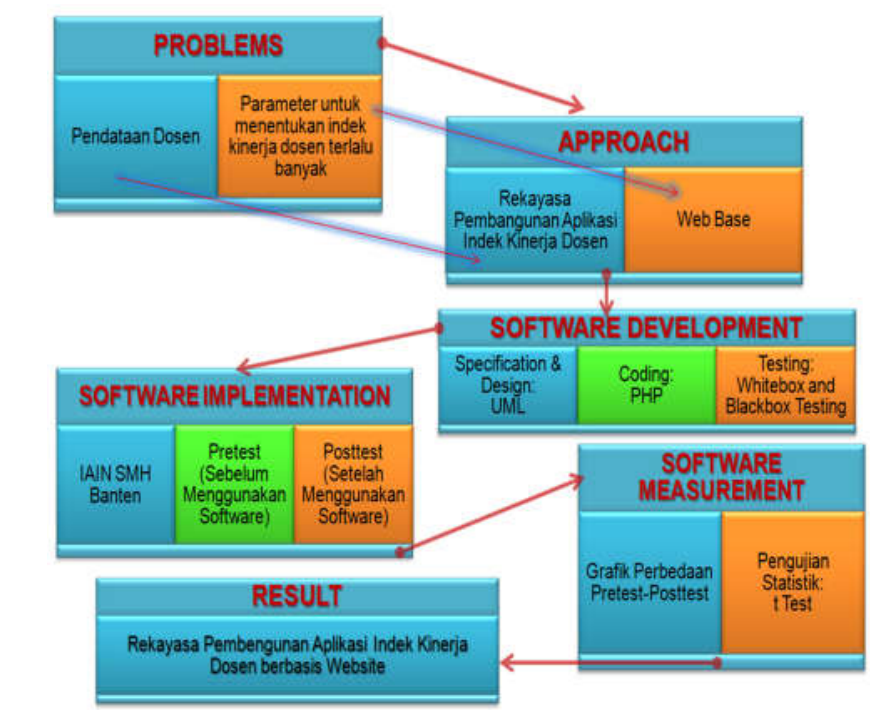

Gambar 4.1. Alur Sistematika Aplikasi Indek Kinerja Dosen

\section{2) Hasil Studi Lapangan}

IAIN SMH Banten merupakan salah satu perguruan tinggi negeri yang berada di Provinsi Banten. Saat ini, IAIN SMH Banten memiliki 3 fakultas yaitu Fakultas Syariah dan Ekonomi Islam, Fakultas Tarbiyah dan Adab, dan Fakultas Ushuluddin dan Dakwah, dengan dosen dimasing-masing faktultas yang tersebar untuk mengajar, meneliti dan mengabdi pada masyarakat sekitar sebagai tri darma perguruan tinggi yang harus dijunjung tinggi oleh dosen yang berada pada naungan IAIN SMH Banten.

Dalam pelaksanaan Tri Dharma Perguruan Tinggi, ketiga fakultas tersebut juga didukung dengan keberadaan lembaga dan unit pelaksana teknis yang bertanggung jawab langsung kepada Rektor. Berikut ini adalah lembaga-lembaga dan unit pelaksana teknis di lingkungan IAIN SMH Banten.

\section{3) Perancangan Aplikasi Indek Kinerja Dosen}

Perancangan pada Rekayasa Pembangunan Aplikasi Indek Kinerja Dosen IAIN SMH Banten diterapkan dalam rancangan pemodelan interaktif yang disesuaikan dengan kebutuhan dari user/pengguna untuk melakukan input data dosen dan yang lainnya yang terkait dengan kinerja dosen.

Langkah pembuatan database MySQL untuk menampung data-data indek kinerja dosen yang diperlukan untuk rekayasa pembangunan aplikasi indek kinerja dosen berbasis website. Sebenarnya tidak hanya MySQL yang bisa digunakan, namun bisa juga SQL Lite atau Posgre SQL. Namun, karena server IAIN SMH Banten 
menggunakan MySQL sebagai format database-nya, maka untuk kesesuaian, digunakan format yang sama yaitu MySQL.

\section{4) Implementasi Aplikasi IKD}

Langkah-langkah dalam implementasi yang di lakukan adalah sebagai berikut:

- Install Web Server

- Install Xampp

- Install Aplikasi IKD

\section{5) Pengujian Aplikasi IKD}

\subsubsection{Form Login}

Aplikasi Indek Kinerja Dosen berbasis web dengan bahasa pemrograman PHP dalam membangun aplikasi ini. Untuk menjalankan aplikasi Indek Kinerja Dosen, pada server atau PC client buka web browser. Pada penelitian ini digunakan Mozilla Firefox untuk memaksimalkan dalam penampilan layar atau dapt juga pada web browser lainnya. Pada bagian address bar, ketikkan http://localhost. Pertama kali aplikasi menampilkan form login.

Masukkan username dan password dan klik login untuk masuk kedalam aplikasi Indek Kinerja Dosen, dan setelah User Name dan password benar maka langsung masuk kedalam halaman menu utama sebagai berikut:

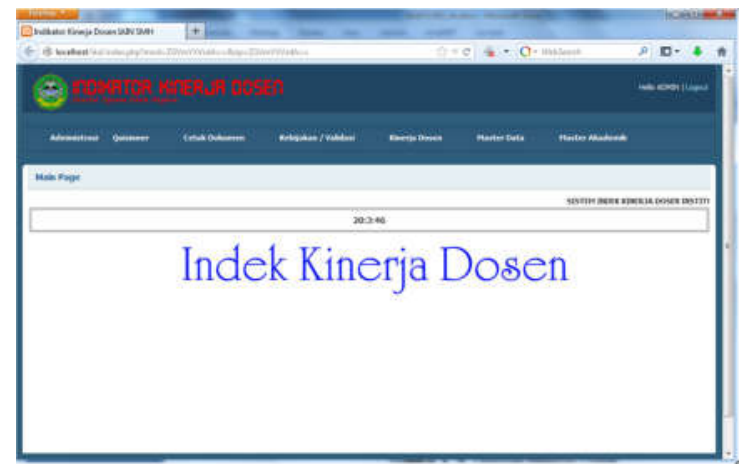

Gambar 4.2. Tampilan Halaman Utama

Halaman menu utama terdiri dari menu :

1.) Administrator : Administrator merupakan menu adamin yang mengurusi semua keperluan user dan pengguna dari operator, dosen/asesor dan mahaiswa.

2.) Operator : Operator merupakan menu pengguna dari pihak penyelenggaran (LPM IAIN SMH Banten) yang berfungsi sebagai pengatur semua kegiatan 
aplikasi Indek Kinerja Dosen.

3.) Asesor/Dosen : Asesor merupakan tim penilai dosen dan Dosen merupakan objek atau dosen yang dinilai oleh asesor.

4.) Mahasiswa : Mahasswa merupakan objek yang menialia kinerja dosen dengan melakukan pengisian kuestioner penilaian dosen.

\section{6) Evaluasi Rekayasa Pembangunan Aplikasi Indek Kinerja Dosen}

\section{Kelebihan dan Kekurangan Aplikasi Indek Kinerja Dosen}

Berdasarkan pengujian yang telah dilakukan, maka dapat diambil kesimpulan atas kinerja dari aplikasi indek kinerja dosen berbasis website ini menjadi hasil analisis yang telah didapat, yaitu: 1).Terdapat 4 (empat) bagian login user yang terdiri dari login Administrator, Login Operator, Login Dosen/asesor dan Login Mahasiswa. 2). Aplikasi ini mempunyai platform berbasis web yang dapat diakses dengan multi platform browser maupun multi platform sistem operasi.

Berdasarkan pengujian dan analisis kinerja sistem baik berupa penanganan kesalahan ataupun pengujian sistem, dapat diperoleh beberapa kekurangan dan kelebihan sistem, diantaranya:

1) Kelebihan

a) Pendataan dosen dari profil dosen samapi dengan kinerja dosen dapat terdatabasekan dengan baik.

b) Dapat diakses dari manapun dan dimanapun selama terkoneksi dengan jaringan komputer.

c) Informasi yang diperoleh akurat cepat dan tepat, karena data yang diperoleh berdasarakan masukan dari masing-masing dosen yang sudah mempunyai hak akses sistem.

d) Penilaian terhadap dosen, yang dilakukan dapat secara objektive karena mahasiswa dapat langsung menilai dosen dengan kuestioner penilaian mahasiswa terhadap dosen.

e) Data penilaian dosen dari masing-masing dosen yang meliputi pengajaran, penelitian dan pengabdian kepada masyrakat dapat dilakukan dengan cara menginputkan data-data tersebut disetiap semesternya.

f) Mekanisme penilaian dapat berjalan otomatis didalam source code program yang telah disesuaikan dengan alur penilaianya yang berada buku pandua kinerja dosen di LPM IAIN SMH Banten.

2) Kekurangan

1. Belum integrasi dengan system informasi akademik (SIAKAD) Kampus yang sudah berjalan terlebih dahulu.

2. Belum dapat digunakan pada fasilitas WAP. 
3. Untuk mendapatkan performa yang baik hendaknya menggunakan browser mozilla, untuk browser yang lainya belum dapat maksimal dalam hal tampilan layar sistem.

4. Format data file yang di-upload kedalam sistem aplikasi IKD masih sebatas jpg, jpeg dan pdf saja.

\section{E. Kesimplan dan Saran \\ Kesimpulan}

Dari hasil pembahasan pada penelitian ini, diperoleh kesimpulan sebagai berikut :

a. Rekayasa pembangunan Aplikasi Indek Kinerja Dosen merupakan aplikasi komputer yang digunakan untuk pendataan dosen yang meliputi pengajaran, penelitian dan pengabdian kepada masyarakat yang dinilai oleh asessor yang terpilih berdasarkan ketentuan-ketentuan yang berlaku untuk mengangkat dosen menjadi asesor.

b. Rekayasa pembangunan Aplikasi Indek Kinerja Dosen merupakan penilaian kinerja dosen dalam melakukan aktivitas pengajaran di kampus dinilai oleh mahasiswa dengan kuestioner yang terdapat pada aplikasi ini, sehingga penilain ini berjalan dengan objektif karena mahasiswa diajar oleh dosen bersangkutan dan menilai dosen yang bersangkutan dengan aplikasi IKD tersebut secara langsung.

c. Rekayasa pembangunan Aplikasi Indek Kinerja Dosen merupakan penilaian kinerja dosen yang dilakuakan secara otomatis pada ketetapan waktu dosen mengumpulkan nilai akhir mahasiswa untuk menginputkan langsung sehingga dosen dapat terdeteksi secara langsung dalam menginput nilai mahasiswa pada sistem jika telat dalam pengumpulan nilai tersebut maka dosen tersebut mendapatkan penilaian kurang baik dan jika tepat waktu maka dosen tersebut mendpatkan penilaian baik juga, adapun untuk ketepatan waktu bukan hanya nilai saja melainkan pengumpulan silabus dan SAP dosen juga mengacu pada ketetntuan tersebut.

d. Dari beberapa penilain tersebut di poin $\mathrm{A}, \mathrm{B}$ dan $\mathrm{C}$ maka dosen dilai secara objektif dan sistematis, sehingga dosen dapat memperbaiki di setiap semester dan setiap tahunnya guna peningkatan kinerjanya, dengan hasil rekap penilaian kinerja masing-masing dosen yang dapat didownload oleh masing-masing dosen dapat memotivasi dosen untuk berprilaku, hari ini harus lebih baik dari hari kemaren. 
e. Dosen harus mencoba dan memulai aplikasi IKD dalam melakukan semua aktifitas kedosenannya seperti halnya yang sudah dilakuakan dalam penilain dosen (BKD) yang hampir sama perlakuanya, yaitu dosen bersentuhan langsung dengan komputer yang sudah tersistem, sehingga data dosen terkoleksi data kinerjanya semua dalam database yang lengkap dan dapat dikases oleh siapapun yang mempuyai otorisasi pada aplikasi IKD, yang akan membantu dan meringkan tugas pekerjaan semua pihak, karena dengan database tersebut dapat dihasilkan output yang tentunya valid berdasarkan database tersebut, seperti kelebihan dan kekurang jam mengajar, ketidakmerataan dalam peneltian dan penulisan dosen yang masih kurang atau kelebihan, aktivitas pengajaran kelas yang tergambar fluktuatifnya akan terlihat, daln lain sebagainya.

\section{Saran}

Rekayasa pembangunan Aplikasi Indek Kinerja Dosen merupakan aplikasi yang dapat meng-database-kan data dosen dari awal kegiatan dan akhir kegiatan dosen dikampus semua terekam dalam database tersebut dan kinerja dosenpun dapat diperoleh hasilnya dari semua aktifitas keberlangsungan dalam proses pemasukan datanya saja, Adapun sistem/aplikasi IKD yang dibentuk sudah dirancang berdasarkan ketentuan-ketentuan yang berlaku di kampus IAIN SMH Banten, sistem berjalan secara otomatis sesuai dengan logika yang sudah dibentuk dalam program/perangkat lunak aplikasi IKD ini, yang pada implementasi dan pelaksanaannya masih banyak perbaikan-perbaikan dan masih adannya beberapa dosen kurang tertarik pada penggunaan teknologi informasi untuk dimungkinkan operator pengguna sistem aplikasi agar membantu dan tak lupa memberikan pelatihan/workshop di awal semesteran atau akhir semsteran dalam rangka penyegaran dan membiasakan dosen untuk bersentuhan langsung dengan teknologi informasi.

\section{Catatan Akhir:}

\footnotetext{
${ }^{1}$ http://niarr91.blogspot.com/2011/02/software-engineering.html

${ }^{2} \mathrm{http} / / /$ kepri.kemenag.go.id/file/file/UndangUndang/lysc1391498449.PDF

${ }^{3} \mathrm{http} / / /$ www.academia.edu/5070215/Penganalan_Internet, Juli 2014

${ }^{4}$ Rudyanto Arief , 2011, Pemrograman Web Dinamis Menggunakan PHP dan MySql : Andi Publisher

${ }^{5}$ Pemrograman Web Dinamis Menggunakan PHP dan MySql : M. Rudyanto Arief

${ }^{6}$ Pemrograman Web Dinamis Menggunakan PHP dan MySql : M. Rudyanto Arief
} 


\section{DAFTAR PUSTAKA}

\section{Sumber Buku:}

Achmad Solichin, 2008. Web dengan PHP dan MySQL. Universitas Budi Luhur, Jakarta.

Adi Nugroho, 2002, Analisa dan Perancangan Sitem Informasi dengan Metodologi Berorientasi Objek. Penerbit INFORMATIKA Bandung..

Jogiyanto 2003. Sistem Teknologi Informasi. Penerbit ANDI Yogyakarta.

Jogiyanto H.M., 2005, Analisis dan Desain Sistem Informasi: pendekatan terstruktur teori dan praktek aplikasi bisnis, Andi, Yogyakarta

Keyes, J. 1993. Software Engineering Productivity Handbook. Mc Graw Hill, New York. Marchiniak, J.J. 1994. Encyclopedia of Software Engineering. John Willey and Sons, New York.

Pressman, Roger S. 2002. Rekayasa Perangkat Lunak, Pendekatan Praktisi (Buku Satu). Penerbit Andi Yogyakarta.

Richardus Eko Indrajit, 2001, Manajemen Sistem Informasi \& Teknologi Informasi. Jakarta: PT. Gramedia.

Rudyanto Arief , 2011, Pemrograman Web Dinamis Menggunakan PHP dan MySql : Andi Publisher

Saputra, Agus. Membangun Aplikasi SMS dengan PHP dan MySQL. 2011

\section{Sumber Internet:}

http://repository.usu.ac.id/bitstream/123456789/30541/3/Chapter\%20II.pdf, Juli 2014 http://kodok.blog.unsoed.ac.id/files/2009/06/software-engineering.pdf, Juli 2014 http://kepri.kemenag.go.id/file/file/UndangUndang/lysc1391498449.PDF, Juli 2014 http://www.academia.edu/5070215/Penganalan_Internet, Juli 2014 
http://firmanstikom.wordpress.com/pengenalan-internet-dan-web-2 , Juli 2014

Aan Anshori, dosen pada Fakultas Syari'ah dan Ekonomi Islam IAIN Sultan Maulana Hasanuddin Banten. 